\section{'Mira' Strawberry}

\author{
A.R. Jamieson ${ }^{1}$, N.L. Nickerson ${ }^{2}$, C.F. Forney ${ }^{3}$, K.A. Sanford ${ }^{4}$, and \\ D.L. Craig ${ }^{5}$ \\ Agriculture and Agri-Food Canada, Atlantic Food and Horticulture Research \\ Centre, 32 Main Street, Kentville, NS, B4N 1J5, Canada
}

Additional index words. Fragaria $\times$ ananassa, Phytophthora fragariae, red stele root rot resistance, fruit breeding

The 'Mira' (pronounced 'Mi-ro) strawberry (Fragaria $\times$ ananassa Duchesne) was commercially introduced in Canada in May 1996 by the Atlantic Food and Horticulture Research Centre of Agriculture and Agri-Food Canada. 'Mira' ripens in late midseason, offering growers an alternative to 'Blomidon', with greater productivity and broader disease resistance. Plants of 'Mira' are vigorous and resistant to red stele root rot disease (incited by Phytophthora fragariae Hickman var. fragariae) and several leaf diseases. Fruit are well formed and have a bright, light red color, which does not darken excessively after harvest or when overripe. 'Mira' is named after the Mira River in Cape Breton, N.S. This river is celebrated by the folk song "Song for the Mira."

\section{Origin}

'Mira', tested as K84-5, is a seedling from a 'Scott' $x$ 'Honeoye' cross made under the direction of D.L. Craig in 1982 at Kentville, N.S. 'Scott' was introduced by the U.S. Dept. of Agriculture at Beltsville, Md., as a latemidseason cultivar with large, firm fruit and excellent disease resistance (Galletta et al., 1980). 'Honeoye' is a widely grown earlymidseason cultivar that is very productive in eastern Canada and northeastern United States, but is susceptible to red stele root rot (Sanford et al., 1982). Seedlings of the cross were screened for red stele resistance using the sand bench method of Scott et al. (1976) with six isolates of race A-6 as inoculum.

\footnotetext{
Received for publication 4 Apr. 2000. Accepted for publication 3 Aug. 2000. Atlantic Food and Horticulture Research Centre Contribution no. 2217. We thank K.B. McRae, S. Fillmore, and B. Walker for assistance with experimental design and analysis. We thank the following cooperators who evaluated 'Mira' for suitability to their area: J-P. Privé and R. Tremblay (New Brunswick), K. Sanderson (Prince Edward Island), P. Hendrickson (Newfoundland), C. Davidson (Manitoba), L. Hausher (Alberta), and D. Wildung (Minnesota). For technical support, we thank A.C. Brydon, M. Graves, P.R. and R.J. Davies, C. Burbidge-Boyd, J. Richards, and K. Nicolas. The cost of publishing this paper was defrayed in part by the payment of page charges. Under postal regulations, this paper therefore must be hereby marked advertisement solely to indicate this fact. ${ }^{1}$ Fruit Breeder.

${ }^{2}$ Mycologist.

${ }^{3}$ Postharvest Physiologist.

${ }^{4}$ Sensory Scientist.

${ }^{5}$ Fruit Breeder, retired.
}

Symptomless plants were moved to a field infested with $P$. fragariae located at Robinsons Corner, Lunenburg Co., N.S., in Spring 1983. 'Mira' was selected in 1984 by A.R.J. and G.W. Bishop (research technician). An additional observation from the pedigree of 'Mira' is that 'Tioga', introduced in 1963 from the Univ. of California and the pollen parent of 'Scott', has figured in the background of several other cultivars from the breeding program, including the important cultivar Kent (Jamieson, 1996).

\section{Description and Performance}

'Mira' has been tested widely in Atlantic Canada in regional trials planted in 1992 and 1994 at Kentville, N.S.; Bouctouche, N.B.; Charlottetown, P.E.I.; and Pynn's Brook, Nfld. An additional trial was planted at Kentville in 1995 to test 'Mira' against late-season cultivars. Trials located in Atlantic Canada consisted of matted rows developed from seven plants set at $60 \mathrm{~cm}$ (in 1992) or $50 \mathrm{~cm}$ (in 1994 and 1995). A 3-m section of each row, centered on the midpoint, was harvested in each trial except the Kentville trial planted in 1995, where $3.5 \mathrm{~m}$ was harvested. Each site had three replicates and plots were harvested for two successive years. 'Mira' has also been tested in the Midwest and Prairie regions of North
Fig. 1. A cluster of 'Mira' strawberries.
America. These trials were also laid out as replicated matted rows but varied as to the number of replications and the length of the rows. In the Atlantic Canada regional trials, the data collected included marketable and unmarketable yield, and fruit weight based on a 25-fruit sample from each row on each harvest date. Mean fruit weight and mean harvest date were calculated on each row and values were weighted by yield as described by Moore (1970) to give seasonal means. Fruit firmness was determined after storage by penetration using an Ametek firmness tester (Ametek, Hunter Spring Division, Hatfield, Pa.) with a 6-mm o.d. v-notched tip. The maximum force that occurred during insertion of the probe $6 \mathrm{~mm}$ into each of 10 fruit was recorded and the 10 values were averaged. An additional 10-fruit sample was used to measure bruising, color, and shine. Bruising was rated subjectively on a scale of 1 (not bruised) to 5 (highly bruised). Color and shine were rated by comparison with Munsell Color Chips (MacBeth, Baltimore). Fruit were also evaluated with a Minolta Chroma Meter CR-200 (Minolta Co., Ramsey, N.J.) to measure darkening during storage. All statistics were calculated with Genstat 5.31 (Payne et al., 1993).

Plants of 'Mira' are vigorous and consistently runner well to fill matted-row beds. Crown size is small to medium; smaller than for 'Kent'. 'Mira' produces longer roots than does 'Kent', which may contribute to drought tolerance. Leaves are trifoliate and the central leaflet is longer than it is wide (1.2 length : 1 width), with an attenuated base and acute serrations. Leaf petioles are long with a low density of outwardly oriented hairs. Flower clusters are produced on long peduncles and flowers open at the height of the canopy. Individual flowers and fruit have long pedicels.

Fruit are medium to large and typically symmetrical and conic in shape, often with a neck (Fig. 1). The larger primary fruit have a

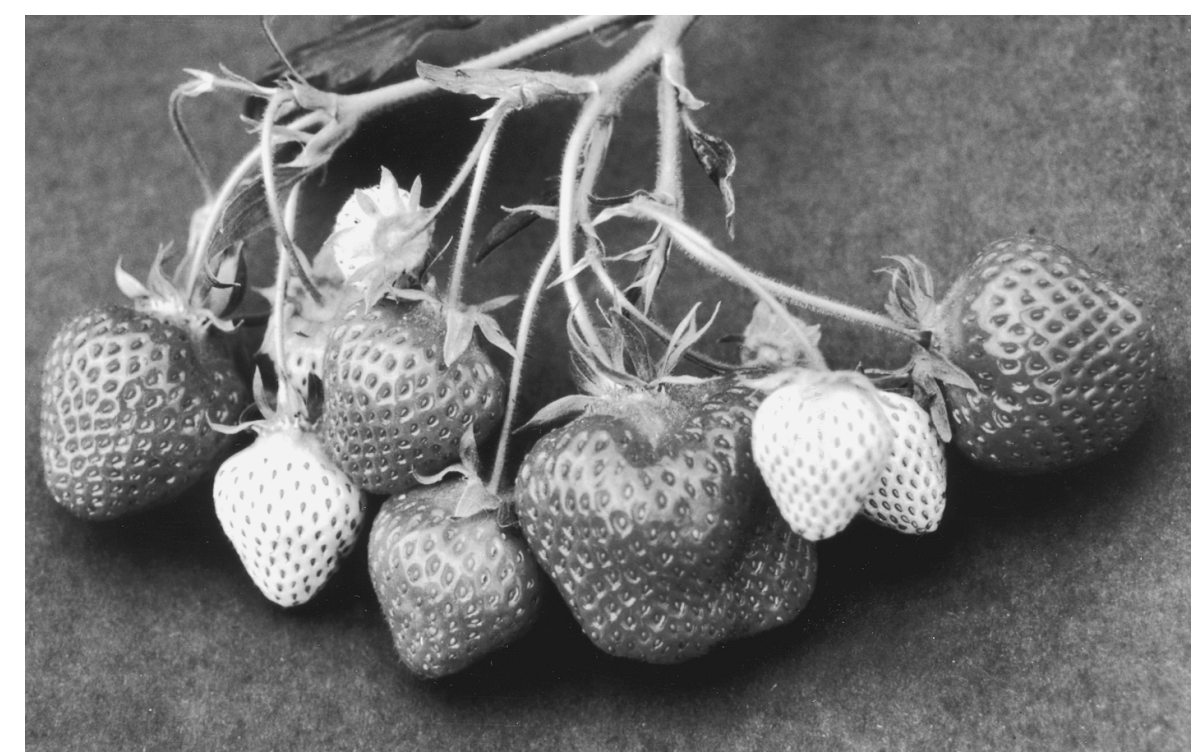


broad tip, giving a wedge shape. Achenes are inserted below the surface of the fruit. The calyx is often reflexed on secondary and tertiary fruit, and its diameter is slightly smaller than the diameter of the fruit. The calyx is more easily removed from the fruit than for 'Kent' and 'Cavendish'. Fruit surface is evenly colored orange-red with a lighter interior color. This color is maintained after harvest. After $7 \mathrm{~d}$ of storage $\left(5 \mathrm{~d}\right.$ at $1{ }^{\circ} \mathrm{C}$ and $2 \mathrm{~d}$ at $15^{\circ} \mathrm{C}$ ), the external hue angle decreased $6 \%$ for 'Mira', $28 \%$ for 'Kent', and $17 \%$ for 'Honeoye', indicating that 'Mira' fruit darkened less than did 'Kent' or 'Honeoye' fruit (data not shown).

Compared with other cultivars used for shipping to distant markets (Table 1), 'Mira' shows similar scores for glossiness (shine) and bruising measured after $7 \mathrm{~d}$ of storage. Firmness measurements for 'Mira' were similar to those for 'Kent' and 'Jewel', but less than for 'Seneca'. The total soluble solids concentration (TSS) of 'Mira' is similar to 'Kent', but 'Mira' has higher titratable acidity (TA); 'Mira' tends to be tart. The consumer acceptance of 'Mira', 'Kent', and 'Cavendish' was measured by a panel composed of 50 to 60 staff members. Panelist scores for the flavor, texture, shape, and overall acceptance of 'Mira' were similar to those for 'Kent' (Table 2).

'Mira' has proven to be very productive (Tables 3 and 4). The highest marketable yield, $32.5 \mathrm{t} \cdot \mathrm{ha}^{-1}$, was produced in the maiden crop year at Kentville in the trial planted in 1995 (Table 4). In the Atlantic provinces, yields of 'Mira' are generally equal to those of 'Kent'. The slight drop in mean second crop yield of 'Mira' in 1996 (Table 3) resulted from accidental herbicide injury affecting two of the three plots at one site. Performance in the western trials, an area where winter-hardiness is a critical cultivar trait, has been less consistent. In Alberta, 'Mira' was evaluated in Brooks and Edmonton (L. Hausher, personal communication). In a trial planted at Brooks in 1996, yields of 'Mira' were $62 \%$ and $40 \%$ of those of 'Kent' in 1997 and 1998, respectively. In a trial planted at Brooks in 1997, yield of 'Mira' was $76 \%$ that of 'Kent' in 1998. In a trial planted at Edmonton in 1997, yields of 'Mira' and 'Kent' were equal in 1998. In Manitoba, 'Mira' was tested in Morden, where yield was $215 \%$ that of 'Honeoye' in 1998 in a trial planted the previous year (C.G. Davidson, personal communication). In Morden, winter injury assessments were based on plant survival (counts) and vigor ratings ( $0-5$, with $0=$ dead and $5=$ very vigorous). 'Mira' had better scores for both categories than did 'Honeoye' or 'Veestar'. In Minnesota, 'Mira' was tested in trials planted in 1997 (D. Wildung, personal communication). Yields of 'Mira' were $42 \%$ and $114 \%$ that of 'Kent' in Excelsior and Grand Rapids, respectively, in 1998. In unmulched plots in Grand Rapids, 'Mira' yielded $96 \%$ as much as did 'Kent'. These Midwestern trials indicate that 'Mira' exhibits adequate winter-hardiness, and that other factors, such as inadequate plant stand
Table 1. Fruit characteristics of 'Mira' and several other cultivars harvested under-ripe (75\% to $95 \%$ red) or red-ripe (100\% red) following storage for $5 \mathrm{~d}$ at $1{ }^{\circ} \mathrm{C}$ and $2 \mathrm{~d}$ at $15{ }^{\circ} \mathrm{C}$.

\begin{tabular}{|c|c|c|c|c|c|c|c|}
\hline Cultivar $^{2}$ & $\begin{array}{c}\text { Fruit maturity } \\
\text { at harvest }\end{array}$ & $\begin{array}{l}\text { Firmness }^{y} \\
(\mathrm{~N})\end{array}$ & $\begin{array}{l}\text { Bruise } \\
\text { rating }^{\mathrm{x}}\end{array}$ & $\begin{array}{l}\text { Color } \\
\text { rating }\end{array}$ & $\begin{array}{l}\text { Shine } \\
\text { rating }^{v}\end{array}$ & $\begin{array}{l}\text { TSS } \\
(\%)\end{array}$ & $\begin{array}{l}\text { TA } \\
(\%)\end{array}$ \\
\hline \multirow{2}{*}{ Jewel } & Underripe & 5.10 & 2.4 & 2.0 & 4.7 & 6.6 & 0.83 \\
\hline & Red ripe & 4.60 & 2.7 & 4.5 & 5.0 & 7.0 & 0.89 \\
\hline \multirow[t]{2}{*}{ Kent } & Underripe & 5.15 & 2.2 & 3.0 & 4.5 & 6.0 & 0.80 \\
\hline & Red ripe & 3.95 & 3.1 & 5.6 & 4.4 & 7.2 & 0.72 \\
\hline \multirow[t]{2}{*}{ Mira } & Underripe & 4.62 & 2.7 & 0.3 & 4.2 & 6.1 & 0.99 \\
\hline & Red ripe & 4.03 & 3.1 & 3.0 & 4.9 & 6.8 & 0.97 \\
\hline \multirow[t]{2}{*}{ Seneca } & Underripe & 6.57 & 2.9 & 3.5 & 5.2 & 6.9 & 0.95 \\
\hline & Red ripe & 5.69 & 3.6 & 6.0 & 5.7 & 6.9 & 0.82 \\
\hline $\operatorname{SEM}(\mathrm{n}=8)$ & & 0.626 & 0.38 & 0.46 & 0.45 & 0.52 & 0.089 \\
\hline Degrees of freedom & & 68.0 & 70.0 & 70.0 & 68.0 & 69.0 & 69.0 \\
\hline
\end{tabular}

${ }^{z ' M i r a ', ~ ' J e w e l ', ~ a n d ~ ' S e n e c a ' ~ w e r e ~ e v a l u a t e d ~ o n ~ t w o ~ h a r v e s t ~ d a t e s ~ f r o m ~ o n e ~ c o m m e r c i a l ~ f i e l d ; ~ ' K e n t ' ~ w a s ~}$ evaluated on two harvest dates from each of three commercial fields.

${ }^{\mathrm{y}}$ Fruit firmness was determined by penetration using an Ametek firmness tester with a 6-mm o.d. v- notched tip. The maximum force that occurred during insertion of the probe $6 \mathrm{~mm}$ into each of 10 fruit was recorded and the 10 values were averaged.

${ }^{x}$ Ratings on a scale of 1 to 5 , where $1=$ not bruised and $5=$ highly bruised.

"Ratings on a scale of 1 to 7, where $1=$ light red and 7= deep red using Munsell Color Chips (MacBeth, Baltimore).

"Ratings on a scale of 1 to 7 , where $1=$ flat and $7=$ high gloss using Munsell Color Chips.

Table 2. Consumer panel evaluation of fruit flavor, texture, shape, and overall acceptability of 'Cavendish', 'Kent', and 'Mira' strawberry grown at Kentville, N.S., in 1993 and $1994 .^{2}$

\begin{tabular}{llccc}
\hline \hline Cultivar & Flavor & Texture & Shape & $\begin{array}{c}\text { Overall } \\
\text { acceptance }\end{array}$ \\
\hline Cavendish & 5.0 & 5.7 & 6.0 & 5.5 \\
Kent & 4.9 & 5.5 & 5.9 & 5.3 \\
Mira & 4.2 & 5.2 & 6.4 & 4.6 \\
SED $^{y}$ (avg) & 0.36 & 0.32 & 0.21 & 0.36 \\
\hline
\end{tabular}

${ }^{2}$ Mean values of scores on a 9-point hedonic score $(1=$ dislike extremely, $9=$ like extremely) as rated within $4 \mathrm{~h}$ of harvest, as part of a larger study.

${ }^{y}$ Standard error of the difference. Components of variation and cultivar means estimated by the Restricted Maximum Likelihood Technique (Payne et al., 1993).

Table 3. Fruit production ${ }^{2}$ of 'Mira' vs. standard strawberry cultivars for 1993 to 1996 averaged over four sites in Atlantic Canada.

\begin{tabular}{|c|c|c|c|c|}
\hline \multirow[b]{2}{*}{ Cultivar } & \multicolumn{2}{|c|}{ Yield $\left(\mathrm{t} \cdot \mathrm{ha}^{-1}\right)$} & \multirow{2}{*}{$\begin{array}{c}\text { Wt/fruit } \\
(\mathrm{g})\end{array}$} & \multirow{2}{*}{$\begin{array}{r}\text { Mean harvest } \\
\text { (day of year) }\end{array}$} \\
\hline & Marketable & Unmarketable & & \\
\hline \multicolumn{5}{|c|}{1993} \\
\hline Annapolis & $11.9 b^{y}$ & $0.9 \mathrm{c}$ & $14.4 \mathrm{~b}$ & 200.2 c \\
\hline Cavendish & $17.6 \mathrm{a}$ & $1.6 \mathrm{ab}$ & $16.4 \mathrm{a}$ & $205.1 \mathrm{~b}$ \\
\hline Kent & $19.2 \mathrm{a}$ & $1.9 \mathrm{a}$ & $14.5 \mathrm{~b}$ & $205.7 \mathrm{~b}$ \\
\hline Mira & $18.1 \mathrm{a}$ & $1.2 \mathrm{bc}$ & $13.7 \mathrm{~b}$ & $208.1 \mathrm{a}$ \\
\hline \multicolumn{5}{|c|}{1994} \\
\hline Annapolis & $14.3 \mathrm{c}$ & $1.2 \mathrm{c}$ & $12.3 \mathrm{~b}$ & $194.6 \mathrm{~d}$ \\
\hline Cavendish & $17.5 \mathrm{~b}$ & $4.0 \mathrm{~b}$ & $14.8 \mathrm{a}$ & $197.3 \mathrm{c}$ \\
\hline Kent & $20.3 \mathrm{a}$ & $4.7 \mathrm{a}$ & $12.3 \mathrm{~b}$ & $198.8 \mathrm{~b}$ \\
\hline Mira & $21.2 \mathrm{a}$ & $3.5 \mathrm{~b}$ & $12.0 \mathrm{~b}$ & 199.9 a \\
\hline \multicolumn{5}{|c|}{1995} \\
\hline Cavendish & $14.9 \mathrm{~b}$ & $1.8 \mathrm{a}$ & $18.8 \mathrm{a}$ & $195.3 \mathrm{c}$ \\
\hline Kent & $19.3 \mathrm{a}$ & $2.2 \mathrm{a}$ & $13.9 \mathrm{~b}$ & $197.0 \mathrm{~b}$ \\
\hline Mira & $21.9 \mathrm{a}$ & $1.9 \mathrm{a}$ & $13.4 \mathrm{~b}$ & $199.0 \mathrm{a}$ \\
\hline Veestar & $11.6 \mathrm{c}$ & $1.2 \mathrm{~b}$ & $8.7 \mathrm{c}$ & $191.5 \mathrm{~d}$ \\
\hline \multicolumn{5}{|c|}{1996} \\
\hline Cavendish & $15.1 \mathrm{ab}$ & $1.7 \mathrm{bc}$ & $12.4 \mathrm{a}$ & $195.4 \mathrm{c}$ \\
\hline Kent & $17.1 \mathrm{a}$ & $2.2 \mathrm{a}$ & $10.4 \mathrm{~b}$ & $197.3 \mathrm{~b}$ \\
\hline Mira & $14.2 \mathrm{a}-\mathrm{c}$ & $1.9 \mathrm{ab}$ & $9.8 \mathrm{~b}$ & $198.3 \mathrm{a}$ \\
\hline Veestar & $11.5 \mathrm{c}$ & $1.3 \mathrm{c}$ & $7.0 \mathrm{c}$ & $193.2 \mathrm{~d}$ \\
\hline
\end{tabular}

${ }^{2}$ Data for 1993 and 1994 from plots established in 1992; data for 1995 and 1996 from plots established in 1994. Data from entire trials, containing 14 cultivars or selections, were used in the analysis of variance.

${ }^{y}$ Mean separation within columns and years by LSD test at $P \leq 0.05$. 
development, may contribute to low yields in some trials.

'Mira' ripens in late midseason. The seasonal average harvest date, when weighted according to the yield at each harvest, is 1 or 2 $\mathrm{d}$ later than for 'Kent' (Table 3). The peak harvest date for 'Mira' is $\approx 5 \mathrm{~d}$ later than for 'Kent' (Fig. 2). Fruit weight, when averaged over the harvest season, is similar to 'Kent', but smaller than that of 'Cavendish' (Table 3 ). As the season progresses, 'Mira' and 'Kent' have similar patterns of reduction in fruit weight (Fig. 2). Both cultivars have a relatively long harvest period.

\section{Disease response}

Fruit rot (caused by Botrytis cinerea Pers.:Fr.) has not been a problem on 'Mira' and, consequently, the unmarketable yield is usually less than for 'Kent' (Table 3). 'Mira' is highly resistant to $P$. fragariae var. fragariae races A-1, A-2, A-3, A-4, A-9, and A-10, and is moderately resistant to A-6 and A-8, as measured in a controlled environment test with potted plants (Nickerson and Murray, 1993). This resistance pattern parallels that of 'Scott' (Maas et al., 1989) with the exception that 'Scott' is resistant to A-7 while 'Mira' is susceptible. Both cultivars are susceptible to A-5. Thus far, this resistance has proven effective in grower trials throughout Nova Scotia. In field plots at Kentville, 'Mira' plants have demonstrated resistance to leaf scorch [caused by Diplocarpon earliana (Ellis \& Everh.) F.A. Wolf] and powdery mildew [caused by Sphaerotheca macularis (Wallr.:Fr.) Jacz. f. sp. fragariae]. Leaf spot
Table 4. Fruit production of 'Mira', 'Blomidon', and 'Bounty' in 1996 and 1997 in matted-row plots established in 1995 at Kentville.

\begin{tabular}{lcccc}
\hline Cultivar & $\begin{array}{c}\text { Marketable } \\
\text { yield }\left(\mathrm{t} \cdot \mathrm{ha}^{-1}\right)\end{array}$ & $\begin{array}{c}\text { Unmarketable } \\
\text { yield }\left(\mathrm{t} \cdot \mathrm{ha}^{-1}\right)\end{array}$ & $\begin{array}{c}\mathrm{Wt} / \text { fruit } \\
(\mathrm{g})\end{array}$ & $\begin{array}{c}\text { Mean harvest } \\
(\text { day of year) }\end{array}$ \\
\hline Blomidon & $23.0 \mathrm{~b}^{\mathrm{z}}$ & 1996 & & \\
Bounty & $24.8 \mathrm{~b}$ & $2.4 \mathrm{a}$ & $13.5 \mathrm{a}$ & $194.3 \mathrm{a}$ \\
Mira & $32.5 \mathrm{a}$ & $2.6 \mathrm{a}$ & $10.4 \mathrm{~b}$ & $197.2 \mathrm{a}$ \\
& & $1.9 \mathrm{a}$ & $11.6 \mathrm{~b}$ & $195.5 \mathrm{a}$ \\
Blomidon & $17.2 \mathrm{a}$ & 1997 & & \\
Bounty & $19.3 \mathrm{a}$ & $0.9 \mathrm{a}$ & $10.8 \mathrm{a}$ & $198.4 \mathrm{a}$ \\
Mira & $19.3 \mathrm{a}$ & $1.6 \mathrm{a}$ & $8.7 \mathrm{~b}$ & $200.5 \mathrm{a}$ \\
& & $1.5 \mathrm{a}$ & $10.8 \mathrm{a}$ & $197.8 \mathrm{a}$
\end{tabular}

${ }^{\mathrm{z}}$ Mean separation within columns and years by LSD test at $P \leq 0.05$.

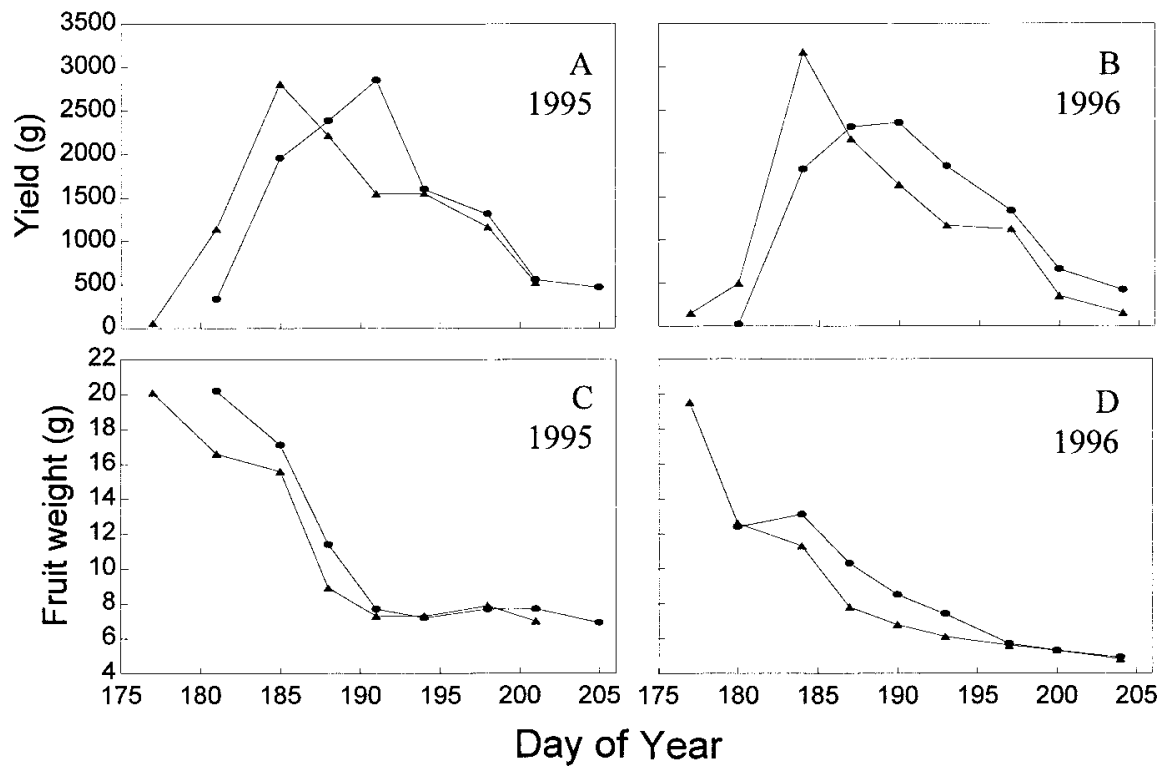

Fig. 2. Yield in grams per $3.0 \mathrm{~m}$ matted row (A and B) and fruit weight (C and D) of 'Kent' ( $\mathbf{A})$ and 'Mira' (O) over the harvest season in 1995 and 1996 in plots established at Kentville in 1994. Data points are the means of measurements for each of the three blocks. [caused by Mycosphaerella fragariae (Tul.) Lindau] has been observed and 'Mira' appears to be susceptible. Virus diseases of strawberries are uncommon in Atlantic Canada, and the virus tolerance of 'Mira' is unknown. Green petal disease (caused by clover phyllody phytoplasma) is common, however, but 'Mira' has not been significantly affected in plots where 'Cavendish' and 'Bounty' have had a high incidence.

'Mira' appears to be well adapted throughout the Atlantic provinces of Canada. In preliminary trials in north-continental climates, the performance of 'Mira' has been more variable. 'Mira' will be of particular value on soils infested with $P$. fragariae var. fragariae, providing a high-yielding cultivar to follow 'Cavendish'. 'Mira' has been preferred at the retail level because of its light color.

\section{Availability}

Certified 'Mira' plants are being propagated under royalty agreements with licensed nurseries, whose names will be supplied upon request. The Atlantic Food and Horticulture Research Centre has been granted Plant Breeder's Rights for 'Mira' (Certificate No. 0215) and a U.S. plant patent (PP11,438) has been issued. Nurseries interested in securing a propagating license may contact the originating station.

\section{Literature Cited}

Galletta, G.J., A.D. Draper, H.D. Stiles, and H.J. Swartz. 1980. 'Scott' strawberry. HortScience 15:541-542.

Jamieson, A.R. 1996. 'Kent' strawberry. Fruit Var. J. 50:138-139.

Maas, J.L., G.J. Galletta, and A.D. Draper. 1989. Resistance in strawberry to races of Phytophthora fragariae and to isolates of Verticillium from North America. Acta Hort. 265:521526

Moore, J.N. 1970. Fruit size of strawberry cultivars. Fruit Var. and Hort. Dig. 24:58-62.

Nickerson, N.L. and R.A. Murray. 1993. Races of the red stele root rot fungus, Phytophthora fragariae, in Nova Scotia. Adv. Strawberry Res. 12:12-16.

Payne, R.W., P.W. Lane, P.G.N. Digby, S.A. Harding, P.K. Leech, G.W. Morgan, A.D. Todd, R. Thompson, G.T. Wilson, S.J. Welham, and R.P. White. 1993. Genstat 5 release 3 reference manual. Clarendon Press. Oxford, U.K.

Sanford, J.C., D.K. Ourecky, J.E. Reich, and H.S. Aldwinckle. 1982. 'Honeoye' and 'Canoga' strawberries. HortScience 17:982-984.

Scott, D.H., A.D. Draper, and J.L. Maas. 1976. Mass screening of young strawberry seedlings for resistance to Phytophthora fragariae Hickman. HortScience 11:257-258. 